\title{
TUMORES METASTÁSICOS EN PENE
}

\author{
C. PELLiCÉ I VILALTA
}

Actas Urol Esp. 27 (3): 248, 2003

\section{Señor Director:}

Recientemente la revista Actas Urológicas Españolas ha publicado el trabajo: "Metástasis peneana de un carcinoma de células renales / 2002; 26: 589-591".

Esta es una nota clínica de correcto redactado y con buen trato dado a la iconografía en ella inserta (TAC, visión quirúrgica y dictamen anatomopatológico).

De revisar su bibliografia, es notoria la ausencia de trabajos de autores españoles y en lengua castellana. La cita aportada en este trabajo ( $n^{\circ}$ 6), hace referencia a unos asientos secundarios en el pene (próstata, vejiga y sigma) pero no de tumor renal.

Es evidente que la presencia de tumores metastásicos renales en el pene es de extrema rareza y ello sólo ya justifica su publicación.

Con anterioridad se aportaron en nuestra literatura casos previos de los que le remito algunos:

- Tumores renales parenquimatosos: citas 2, 4, 5 y 6 (3 casos).

- Tumores de pelvis renal: citas 1 y 3 ( 2 casos).

\section{REFERENCIAS}

1. HERNÁEZ I, AURTENECHE J.: Metástasis peneana de un carcinoma transicional renal. Actas Urol Esp 1985; 9: 435-436.

2. GARCÍA F, GARCÍA J, TOMAS M y cols.: Infiltración neoplásica del pene secundaria a tumores de origen diverso. Nuestra experiencia. Congreso Nacional de la AEU. Murcia 2002: 185.

3. LLOPIS B, ALONSO M, VALLS F y cols.: Tumores secundarios de pene. Actas Urol Esp 1986; 10: 167170.

4. MARCHAL C, CONTRERAS J, CHICHARRO J y cols.: Enfermedad metastásica del pene. A propósito de tres casos. Actas Urol Esp 1993; 17: 461-463.

5. MORGA J, FERRERO R, GUZMÁN P y cols.: Priapismo metastásico. Presentación de cuatro nuevos casos y revisión de la literatura. Arch Esp Urol 2000; 53: 447452.

6. RAMOS J, GONZÁLEZ J, GÓMEZ V, MONTERO J.: Priapismo como primera manifestación de un hipernefroma. Actas Urol Esp 1982; 6: 373-376.

Dr. C. Pellicé i Vilalta

Felipe II, 27-29, 6을 $1^{\text {a }}$ B

08027 Barcelona

(Trabajo recibido el 15 octubre de 2002) 